\section{September Flowering of the Horse-Chestnut}

Mr. F. B. Hutchinson of 36, St. Aubyns, Hove, Sussex, writes that early in September in Luxemburg, he noticed that two horse-chestnut trees (Asculus Hippocastanum) in the Place Guillaume were in full flower. The square contained about twenty-four trees, all bearing abundant fruit except the two in flower in the extreme north-east corner; these had only flowers and new green leaves. On the normal trees the leaves were turning brown at the edge and some had already fallen. On the two flowering trees, all the leaves produced in the spring had turned completely brown and most of them had dropped off, while the buds which usually remain dormant during the winter had opened to produce fresh green leaves and apical inflorescences, leaving the bud scales scattered on the ground beneath. It is, perhaps, significant that the winter bud of Asculus normally contains the next year's shoot and inflorescence in a very advanced stage of development. The flowers are normally produced in May.

\section{Bee Flowers}

Mr. H. S. Boothman of Nightingale Nursery, Furze Platt, Maidenhead, has issued a list of bee flowers which will be very welcome to all bee-keepers who desire to establish beautiful gardens to assist their apiaries. A wide variety of annuals, biennials and perennials, in addition to bulbs, shrubs and heathers, is included, and special attention is given to plants flowering in late autumn, winter and early spring. The bees are not, of course, working very hard at these times, but it is claimed that the proximity of bee flowers to the hive will provide them with nectar when they fly out on sunny days, and thus economise the stored honey. Such plants as the Christmas rose (Helleborus niger), the 'golden wings' variety of Solidago, Galanthus Elwesi, the winter aconite (Eranthis hyemalis), Erica carnea and $E$. darleyensis are suitable for this purpose. Mr. Boothman can supply the seeds and plants mentioned in the list.

\section{The Sky in October}

OCTOBER will be a favourable month for seeing most of the planets. Mercury will be visible as an evening star; it reaches its greatest eastern elongation on October 28, when it will set an hour and a half after the sun. Without a telescope one can only conveniently see Mercury on these occasions of eastern elongation; choose a site with a good view of the western horizon and keep a sharp look-out just after sunset. Venus will also be visible in the evening sky. At the end of October this planet will set three hours after the sun. It will be a brilliant object (the stellar magnitude will be $-3 \cdot 8$ ). On October 14 there will be a conjunction of Venus and Mars. Actual conjunction takes place at 11 hours, that is, in broad daylight, but the close positions of the two planets just after sunset on the following evening should form an interesting sight, especially if Mercury is seen as well. Jupiter will only just have passed its conjunction with the sun, and so will be invisible, but Saturn will again be visible in the southern sky throughout the night. Finally, Uranus will be in opposition on October 19.

\section{Announcements}

.Mr. J. P. Bushe-Fox, inspector of ancient monuments for England, has been appointed chief inspector of ancient monuments in succession to Sir Charles Peers, who has retired on attaining the age limit.

Prof. A. Einstein will address a meeting to be held at the Royal Albert Hall, London, on October 3, under the auspices of the Society of Friends, the International Student Service, the Refugee Professionals Committee, and the Academic Assistance Council. Lord Rutherford will preside, and Sir Austen Chamberlain and others will also speak. The object of the meeting is to raise funds for refugees from Germany. Tickets can be obtained from the Refugee Assistance Fund, 54 St. Stephen's House, Westminster, S.W.1.

A sxmposium on "Bread and Milk" has been arranged by the Food Group of the Society of Chemical Industry, to be held in the hall of the British Medical Association, Tavistock Place, London, W.C.1, on November 23-24. The symposium will be divided into three sessions under the respective presidencies of Prof. W. W. Jameson, Sir John Russell and Prof. H. E. Armstrong. It will be international in character and several prominent foreign men of science have been invited to contribute to the proceedings.

ApPlications are invited for the following appoint. ments, on or before the dates mentioned :-A teacher of domestic subjects at the Yorkshire Training College of Housecraft, Vernon Road, Leeds-The Director of Education, Education Offices, Calverley Street, Leeds (Oct. 2). An engineering assistant in the Water Department of the County Borough of Wolverhampton-The Town Clerk, Town Hall, Wolverhampton (Oct. 5). A civil engineering assistant in the Water Department of the City of Lincoln-The Water Engineer and Manager, Water Engineer's Office, 4, Lindum Road, Lincoln (Oct. 6). A principal of the Dudden Hill Technical Institute, Denzil Road, Willesden, London, N.W.10-H.M. Walton (H.), Secretary, 10, Great George Street, Westminster, London, S.W.1 (Oct. 7). An explosives chemist at the Royal Gunpowder Factory, Waltham Abbey-Principal Clerk, Central Office, Royal Gunpowder and Small Arms Factories, Enfield Lock, Middlesex (Oct. 13). An assistant lecturer in mechanical engineering in the College of Technology, with the title and status of assistant lecturer in the University of Manchester-The Registrar, College of Technology, Manchester (Oct. 16). A lecturer in physiology in the University of Bristol-Winifred Shapland, Secretary and Registrar (Oct. 20). Evening lecturers in strength of materials, mathematics, electrical technology, thermodynamies, theory of machines and machine design at the Acton Technical College-H. M. Walton (H.), Secretary, 10, Great George Street, Westminster, London, S.W.1. 